JOURNAL OF SECURITY AND SUSTAINABILITY ISSUES

ISSN 2029-7017 print/ISSN 2029-7025 online

2021 Volume 11

http://doi.org/10.47459/jssi.2021.11.5.

\title{
THE EDUCATION OF PRISON SERVICE OFFICERS: TENDENCIES AND CHANGES IN THE FRAMEWORK OF SECURITY
}

\author{
Dorota Kanarek-Lizik \\ Higher School of Criminology and Penitentiary Science in Warsaw, st. Wiśniowa 50, 02-520 Warsaw, Poland \\ E-mail:dorota.kanarek-lizik@wskip.edu.pl
}

Received 10 October 2020; accepted 25 February 2021; published 30 March 2021

\begin{abstract}
The article presents the current patterns in education of Prison Service officers on the example of one of the largest penitentiary units in Poland, i.e. the Penitentiary Facility in Włocławek. The tendencies and changes in provision by qualified staff in penitentiary system as a prerequisite of societal safety were defined due to analysis of data about education of officers of the Prison Service and penitentiary department in the years 1999-2019. In order to investigate the role of rehabilitation staff in the penitentiary system, it is important to assess the current distribution and structural changes in penitentiary staff which, in turn, can be crucial for achieving the objectives of the execution of the imprisonment penalty. To achieve and maintain societal safety, particularly security in penitentiary system it is important to consider changes in the capacity of the prisons. In this regard main positive trends are: increase of number and share of staff with special tertiary education affects the quality of the social rehabilitation work at the penitentiary facility; gender distribution of Prison Service staff tends to reflect distribution on prisoners; professional qualification of officers grows steadily. The main challenge for current penitentiary system in order to increase its educational impact on prisoners is hiring process which should be directed on attracting graduates of rehabilitation pedagogy and penitentiary pedagogy to work in the penitentiary department.
\end{abstract}

Key words: education; personnel structure; penitentiary facility; Poland; security

Reference to this paper should be made as follows: Kanarek-Lizik, D. 2021. The education of prison service officers: tendencies and changes in the framework of security. Journal of Security and Sustainability Issues, 11, 83-90. http://doi.org/10.47459/jssi.2021.11.5.

JEL Classifications: I31, I38

Additional disciplines: education; security science; sociology

\section{Introduction.}

Security in penitentiary system cannot be achieved without appropriate changes in educational level of the staff, which, in their turn, depends a lot on the capacity and quality of the educational system (Hamdan \& Hamdan, 2020; Mazzanti et al., 2020; Vasconcelos, 2021). It is proved for different market sectors and stages of economic development (Bilan et al., 2019; Máté et al., 2018; Alkhateeb et al., 2020; Poltarykhin et al., 2020).

For such specific field of occupation as penitentiary system the importance of professional education increases significantly due to its impact on state security (Kośmider, 2018; Strzelec et al., 2019; Chehabeddine \& Tvaronavičiene, 2020) Considering this fact, in this research the current tendencies and changes of education are investigated based on experience of one of the most powerful penitentiary institutions in Poland. The Penitentiary Facility in Włocławek is located in the Kuyavian-Pomeranian Voivodeship. The prison falls under the District Inspectorate of the Prison Service in Bydgoszcz.

It is a penitentiary for men: juveniles, those serving a sentence for the first time and penitentiary recidivists. The 
penitentiary has the following wards: a detention centre, semi-open penitentiary for juveniles and semi-open penitentiary for first-time prisoners. In addition, there is a therapeutic ward for inmates addicted to narcotic drugs or psychoactive substances as well as a ward for inmates requiring detention in a designated ward or cell of the detention centre or penitentiary facility in conditions ensuring increased public security and protection, i.e. a ward for dangerous inmates. On the premises of the penitentiary facility operates the Centre of Continuing Education No. 2 in Włocławek, which predominantly provides vocational qualification courses for convicts. The capacity of the prison was set at 1,220 people. The Penitentiary Facility in Włocławek is one of the largest penitentiaries in Poland.

The article presents the changes in education of Prison Service officers at the Penitentiary Facility in Włocławek as well as the penitentiary department in the years 1999-2019. The author selected the penitentiary department for the presentation of data relating to the number and educational background of the Prison Service officers because in her opinion, the role of rehabilitation staff in the organisational structure of a penitentiary facility is essential, particularly in terms of achieving the objectives of the execution of the imprisonment penalty (Executive Penal Code 1997, Art. 67).

The organisational structure of the Penitentiary Facility in Włocławek is as follows: Management and independent positions, Human Resources Department, Penitentiary Department, Therapeutic Department, Security Department, Records Department, Finance Department, Quartermaster Department, Technology, Communication and IT Department, Outpatient Clinic with an Infirmary, Centre of Continuing Education.

\section{The number of Prison Service officers at the Penitentiary Facility in Wloclawek}

The number of Prison Service officers at the Penitentiary Facility in Włocławek in the years 1999-2019 ranged from 277 to 331. In 1999, the penitentiary facility employed 283 prison officers, while in 2019, 327 (Table 1).

We observe an increase in the number of prison officers in the analysed period. The lowest number of prison officers was recorded in 2000 and 2003 (277), and the highest in 2018 (331). The upward trend in the number of prison officers is related to, among others, the increasing capacity of the prison, which in the years 1999-2019 ranged from 929 to 1,258 places (https://www.sw.gov.pl/strona/statystyka-roczna). (See Table 1).

Table 1. The number of Prison Service officers at the Penitentiary Facility in Włocławek in the years 1999-2019

\begin{tabular}{|c|c|c|c|c|c|}
\hline \multirow{2}{*}{ Years } & \multirow{2}{*}{ Number of Prison Service officers } & \multicolumn{4}{|c|}{ Sex } \\
\hline & & Females & $\%$ & Males & $\%$ \\
\hline 1999 & 283 & 15 & 5.3 & 268 & 94.7 \\
\hline 2000 & 277 & 15 & 5.4 & 262 & 94.6 \\
\hline 2001 & 279 & 16 & 5.7 & 263 & 94.3 \\
\hline 2002 & 279 & 16 & 5.7 & 263 & 94.3 \\
\hline 2003 & 277 & 20 & 7.2 & 257 & 92.8 \\
\hline 2004 & 285 & 24 & 8.4 & 261 & 91.6 \\
\hline 2005 & 285 & 23 & 8.1 & 262 & 91.9 \\
\hline 2006 & 285 & 21 & 7.4 & 264 & 92.6 \\
\hline 2007 & 300 & 24 & 8.0 & 276 & 92.0 \\
\hline 2008 & 313 & 26 & 8.3 & 287 & 91.7 \\
\hline 2009 & 319 & 31 & 9.7 & 288 & 90.3 \\
\hline 2010 & 317 & 32 & 10.1 & 285 & 89.9 \\
\hline 2011 & 315 & 36 & 11.4 & 279 & 88.6 \\
\hline 2012 & 315 & 38 & 12.1 & 277 & 87.9 \\
\hline 2013 & 315 & 41 & 13.0 & 274 & 87.0 \\
\hline 2014 & 316 & 43 & 13.6 & 273 & 86.4 \\
\hline 2015 & 312 & 46 & 14.7 & 266 & 85.3 \\
\hline 2016 & 317 & 45 & 14.2 & 272 & 85.8 \\
\hline
\end{tabular}




\begin{tabular}{|l|l|l|l|l|l|}
\hline 2017 & 307 & 45 & 14.7 & 262 & 85.3 \\
\hline 2018 & 331 & 48 & 14.5 & 283 & 85.5 \\
\hline 2019 & 327 & 48 & 14.7 & 279 & 85.3 \\
\hline
\end{tabular}

Source: own elaboration based on data obtained from the Penitentiary Facility in Włocławek

The data in Table 1 shows that in the years 1999-2019, men constituted the vast majority of the Prison Service officers. The largest number of male Prison Service officers, i.e. $94.7 \%$, served in the penitentiary facility in 1999, while the lowest number, i.e. from $85.3 \%$ to $85.8 \%$, in the years $2015-2019$. The percentage of female Prison Service officers grew systematically in the analysed period. In 1999, 5.3\% of the Prison Service officers were female, while in 2019, 14.7\%. The low percentage of women serving as Prison Service officers can be largely attributed to the personnel policy of the prison system. When employing new Prison Service officers, a penitentiary facility/detention centre is most often guided by the purpose of the penitentiary. It is believed that if a penitentiary/detention centre is intended for male inmates, men should dominate the structure of the prison staff. The Penitentiary Facility in Włocławek is an example of such an approach in the personnel policy of the prison system. An upward trend is observed in the number of Prison Service officers in the penitentiary department in the years 1999-2019. The lowest number of officers in this department, i.e. 24 people, were employed by the prison in 2000, while the highest, i.e. 48 people, in 2018 (Table 2). The vast majority of the Prison Service officers of the penitentiary department have been men, particularly in the years 1999-2003 (more than $80 \%$ ). The lowest percentage of men in the penitentiary department was recorded in 2019, i.e. 57.8\%. Female Prison Service officers constitute a minority in the penitentiary department. In 1999 and 2000, the percentage of women was only $8 \%$ and $8.3 \%$, respectively. However, it should be noted that the number of women in the penitentiary department has been steadily increasing and in 2019 , reached $42.2 \%$. This percentage is almost three times higher than the percentage of female Prison Service officers in the entire penitentiary (see Table 2).

Table 2. Educational background of Prison Service officers of the penitentiary department of the Penitentiary Facility in Włocławek in 1999-2019

\begin{tabular}{|c|c|c|c|c|c|}
\hline \multirow{2}{*}{ Years } & \multirow{2}{*}{$\begin{array}{c}\text { Number of Prison Service officers } \\
\text { of the penitentiary department }\end{array}$} & \multicolumn{4}{|c|}{ Sex } \\
\cline { 3 - 6 } & 25 & Females & $\%$ & Males & $\%$ \\
\hline 1999 & 24 & 2 & 8.0 & 23 & 92.0 \\
\hline 2000 & 26 & 2 & 8.3 & 22 & 91.7 \\
\hline 2001 & 26 & 3 & 11.5 & 23 & 88.5 \\
\hline 2002 & 28 & 3 & 11.5 & 23 & 88.5 \\
\hline 2003 & 34 & 5 & 17.9 & 23 & 82.1 \\
\hline 2004 & 30 & 8 & 23.5 & 26 & 76.5 \\
\hline 2005 & 29 & 6 & 20.0 & 24 & 80.0 \\
\hline 2006 & 31 & 6 & 20.7 & 23 & 79.3 \\
\hline 2007 & 32 & 7 & 22.6 & 24 & 77.4 \\
\hline 2008 & 35 & 8 & 25.0 & 24 & 75.0 \\
\hline 2009 & 37 & 9 & 25.7 & 26 & 74.3 \\
\hline 2010 & 37 & 10 & 27.0 & 27 & 73.0 \\
\hline 2011 & 38 & 11 & 29.7 & 26 & 70.3 \\
\hline 2012 & 40 & 13 & 28.9 & 27 & 71.1 \\
\hline 2013 & 42 & 14 & 32.5 & 27 & 67.5 \\
\hline 2014 & 42 & 16 & 38.1 & 28 & 66.7 \\
\hline 2015 & 42 & 17 & 40.5 & 26 & 61.9 \\
\hline 2016 & 44 & 18 & 40.9 & 26 & 59.5 \\
\hline 2017 & 48 & 19 & 39.6 & 29 & 59.1 \\
\hline 2018 & 45 & 19 & 42.2 & 26 & 57.4 \\
\hline 2019 & & & & & \\
\hline
\end{tabular}

Source: own elaboration based on data obtained from the Penitentiary Facility in Włocławek 


\section{Educational background of Prison Service officers at the Penitentiary Facility in Wloclawek}

The officers' education is regulated by the Act of 9 April 2010 on the Prison Service. In accordance with Art. 44, to hold officer positions, it is required to have a master's degree, while to hold standard-bearer positions, a bachelor's degree is essential. Secondary education is mandatory for non-commissioned positions. In 2020, 85 people were employed as officers at the Penitentiary Facility in Włocławek. Additionally, 41 positions of standard-bearer and 216 positions of non-commissioned officers were also filled. In total, 342 prison officers served in the penitentiary. Moreover, the penitentiary employs civilian employees, i.e. state officials, pedagogical workers and others (Order No. 89/2020 of the Director of the Penitentiary Facility in Włocławek). In the years 1999-2019, people with secondary education prevailed in the prison. The largest number of prison officers with secondary education, i.e. $76.3 \%$, worked at the penitentiary facility in 2002, and the lowest, in 2017 (51.5\%). The high percentage of people with secondary education is attributed to the high number of officers employed in the security department, where non-commissioned officers, whose positions require secondary education, constitute the majority. Due to the high capacity of the penitentiary, the security department must be large (Table 3). The largest number of prison officers with higher education (bachelor's or master's degrees), i.e. $\geq 48 \%$, were employed in the penitentiary in 2015-2018. The smallest number of officers, who graduated from universities, i.e. $13.4 \%$, worked in the penitentiary in 1999. Until 2012, prison officers with basic and basic vocational education also served in the prison. In 1999, the percentage of officers with basic and basic vocational education was comparable to that of university graduates employed in the penitentiary, i.e. $13.1 \%$ and $13.4 \%$, respectively.

Table 3. Educational background of Prison Service officers in the Penitentiary Facility in Włocławek in 1999-2019

\begin{tabular}{|c|c|c|c|c|c|c|}
\hline \multirow{2}{*}{ Years } & \multicolumn{6}{|c|}{ Education } \\
\hline & Basic and Basic Vocational & $\%$ & Secondary & $\%$ & Higher & $\%$ \\
\hline 1999 & 37 & 13.1 & 208 & 73.5 & 38 & 13.4 \\
\hline 2000 & 31 & 11.2 & 206 & 74.4 & 40 & 14.4 \\
\hline 2001 & 27 & 9.7 & 207 & 74.2 & 45 & 16.1 \\
\hline 2002 & 18 & 6.5 & 213 & 76.3 & 48 & 17.2 \\
\hline 2003 & 12 & 4.3 & 208 & 75.1 & 57 & 20.6 \\
\hline 2004 & 11 & 3.8 & 206 & 72.3 & 68 & 23.9 \\
\hline 2005 & 12 & 4.1 & 205 & 72.0 & 68 & 23.9 \\
\hline 2006 & 15 & 5.3 & 193 & 67.7 & 77 & 27.0 \\
\hline 2007 & 20 & 6.7 & 192 & 64.0 & 88 & 29.3 \\
\hline 2008 & 19 & 6.0 & 197 & 63.0 & 97 & 31.0 \\
\hline 2009 & 20 & 6.3 & 193 & 60.5 & 106 & 33.2 \\
\hline 2010 & 21 & 6.6 & 186 & 58.7 & 110 & 34.7 \\
\hline 2011 & 18 & 5.7 & 178 & 56.5 & 119 & 37.8 \\
\hline 2012 & 16 & 5.1 & 168 & 53.3 & 131 & 41.6 \\
\hline 2013 & 0 & 0 & 181 & 57.5 & 134 & 42.5 \\
\hline 2014 & 0 & 0 & 177 & 56.0 & 139 & 44.0 \\
\hline 2015 & 0 & 0 & 162 & 51.9 & 150 & 48.1 \\
\hline 2016 & 0 & 0 & 165 & 52.0 & 152 & 48.0 \\
\hline 2017 & 0 & 0 & 158 & 51.5 & 149 & 48.5 \\
\hline 2018 & 0 & 0 & 172 & 52.0 & 159 & 48.0 \\
\hline 2019 & 0 & 0 & 172 & 52.6 & 155 & 47.4 \\
\hline
\end{tabular}

Source: own elaboration based on data obtained from the Penitentiary Institution in Włocławek

In terms of the percentage of officers with secondary and higher education, the data relating to the education of Prison Service officers at the Penitentiary Facility in Włocławek are comparable with the data on the education of prison officers at the Penitentiary Facility in Inowrocław (Kanarek-Lizik D., Stankowski W., 2014). On the example of these penitentiary units, the following tendency is observed: over the analysed period, the percent- 
age of people with secondary education decreased, while the percentage of people with higher education increased. This means that the Prison Service officers at these facilities improved their professional qualifications.

The penitentiary department is dominated by Prison Service officers employed in officer positions, which require master's degrees. According to the list of official positions in the penitentiary department, we distinguish the following positions: manager, deputy manager, psychologist, counsellor (including employment counsellor) as well as inspector and prison officer instructor. A bachelor's degree is required for the positions of inspector and prison officer instructor (Order No. 89/2020 of the Director of the Penitentiary Facility in Włocławek).

In the years 1999-2013, people with both secondary and higher education were employed in the penitentiary department; however, those with higher education accounted for the majority. Since 2014, the penitentiary department includes only people with higher education (Table 4).

Table 4. Education of Prison Service officers of the penitentiary department at the Penitentiary Facility in Włocławek in 1999-2019

\begin{tabular}{|c|c|c|c|}
\hline \multirow{2}{*}{ Years } & \multicolumn{2}{|c|}{ Education } & \multirow{2}{*}{ Completed field of study } \\
\hline & Secondary & Higher & \\
\hline 1999 & 8 & 17 & lack of data* \\
\hline 2000 & 7 & 17 & \\
\hline 2001 & 5 & 21 & \\
\hline 2002 & 5 & 21 & \\
\hline 2003 & 5 & 23 & \\
\hline 2004 & 5 & 29 & \\
\hline 2005 & 4 & 26 & \\
\hline 2006 & 3 & 26 & \\
\hline 2007 & 2 & 29 & \\
\hline 2008 & 2 & 30 & \\
\hline 2009 & 2 & 33 & \\
\hline 2010 & 2 & 35 & \\
\hline 2011 & 1 & 36 & \\
\hline 2012 & 1 & 37 & \\
\hline 2013 & 1 & 39 & \\
\hline 2014 & 0 & 42 & $\begin{array}{l}3 \text { - administration, } 30 \text { - pedagogy (various specialties, including social rehabilitation education - 7), } \\
5 \text { - psychology, } 1 \text { - physical education, } 1 \text { - management, } 1 \text { - law, } 1 \text { - international relations }\end{array}$ \\
\hline 2015 & 0 & 42 & $\begin{array}{l}2 \text { - administration, } 29 \text { - pedagogy (various specialties, including social rehabilitation education - 6), } \\
\text { 7- psychology, } 2 \text { - physical education, } 1 \text { - management, } 1 \text { - law }\end{array}$ \\
\hline 2016 & 0 & 42 & $\begin{array}{l}2 \text { - administration, } 29 \text { - pedagogy (various specialties, including social rehabilitation education - 6), } \\
\text { 7- psychology, } 2 \text { - physical education, } 1 \text { - management, } 1 \text { - law }\end{array}$ \\
\hline 2017 & 0 & 44 & $\begin{array}{l}2 \text { - administration, } 1 \text { - history, } 30 \text { - pedagogy (various specialties, including social rehabilitation } \\
\text { education - } 6 \text { ), } 6 \text { - psychology, } 3 \text { - physical education, } 2 \text { - management }\end{array}$ \\
\hline 2018 & 0 & 48 & $\begin{array}{l}3 \text { - administration, } 1 \text { - history, } 34 \text { - pedagogy (various specialties, including social rehabilitation } \\
\text { education - 6), } 6 \text { - psychology, } 3 \text { - physical education, } 1 \text { - management }\end{array}$ \\
\hline 2019 & 0 & 45 & $\begin{array}{l}2 \text { - administration, } 1 \text { - history, } 30 \text { - pedagogy (various specialties, including social rehabilitation } \\
\text { education - 6), } 6 \text { - psychology, } 3 \text { - physical education, } 2 \text { - management }\end{array}$ \\
\hline
\end{tabular}

Source: own elaboration based on data obtained from the Penitentiary Facility in Włocławek

(*) - In the years 1999-2013, no data relating to the field of study completed by the Prison Service officers of the penitentiary department was collected at the Penitentiary Facility in Wtoclawek.

The analysis of the data summarised in Table 4 indicates that in the years 2014-2019, Prison Service officers of the penitentiary department most often graduated from the field of study of pedagogy. They completed various specialties, which most often differed from the major, i.e. social rehabilitation education. Graduates of social rehabilitation education are a minority in the penitentiary department. There are no graduates of penitentiary pedagogy among the employees of the penitentiary department. 


\section{Conclusions}

As a summary of the above considerations, the author made the following conclusions:

1. The total number of Prison Service officers in the penitentiary facility in the years 1999-2019 ranged from 277 to 331 officers. The lowest number of Prison Service officers was recorded in 2000 and 2003 (277), and the highest in 2018 (331). The increase in the number of Prison Service officers is related to, among others, the increasing capacity of the prison, which in the analysed period ranged from 929 to 1,258 places.

2. The number of Prison Service officers at the penitentiary department in the years 1999-2019 increased significantly. The smallest number of officers in this department, i.e. 24 people, were employed by the penitentiary facility in 2000, and the highest, i.e. 48 people, in 2018. Thus, the number of employees of the penitentiary department in the analysed period doubled. The increase in the number of Prison Service officers in the penitentiary department affects the quality of the social rehabilitation work at the penitentiary facility; therefore, it is advisable that this trend is maintained.

3. In the years 1999-2019, men constituted the vast majority of all Prison Service officers. The largest number of male Prison Service officers, i.e. $94.7 \%$, served at the penitentiary facility in 1999, while the lowest number, i.e. from $85.3 \%$ to $85.8 \%$, in the years $2015-2019$. The percentage of female Prison Service officers grew systematically. In 1999, they accounted for 5.3\% of all Prison Service officers, while in 2019, for 14.7\%. In light of the above data, it should be stated that the pace of the increase of the number of female Prison Service officers at the penitentiary facility is too slow.

The low percentage of women employed at the facility is largely a consequence the staff policy of the prison system. Specifically, when hiring new Prison Service officers, the penitentiary/detention centre is most often guided by the purpose of the penitentiary facility. It is believed that if a penitentiary facility is intended for male inmates, men should dominate the structure of the prison staff. Based on many years of penitentiary practice (Kanarek-Lizik D., Stankowski W., 2014), the author believes that when employing Prison Service officers, one should primarily be guided by their professional qualifications as well as physical and mental predispositions to work in a rehabilitation institution, and to a lesser extent by the purpose of the penitentiary facility.

4. Women in the penitentiary department are in the minority. In 1999 and 2000, the percentage of women was only $8 \%$ and $8.3 \%$, respectively. Nonetheless, the number of women in the penitentiary department has been steadily growing and in 2019 , reached $42.2 \%$. This percentage is almost three times higher than the percentage of female Prison Service officers in the entire penitentiary facility.(Marcin Strzelec,2019.) It is advisable to maintain this pace of increase in the number of women in the penitentiary department. (Strzelec M., 2019).

5. In the years 1999-2019, people with secondary education prevailed at the penitentiary facility. The highest number of officers with secondary education at the penitentiary facility, i.e. $76.3 \%$, was recorded in 2002 , while the lowest, i.e. $51.5 \%$, in 2017.

The largest number of Prison Service officers with higher education (bachelor's or master's degrees), i.e. $\geq 48 \%$, were employed in the penitentiary in 2015-2018. The smallest number of officers, who graduated from universities, i.e. $13.4 \%$, worked at the penitentiary facility in 1999. Until 2012, Prison Service officers with primary and basic vocational education also served in the prison.

On the example of the Penitentiary Facility in Włocławek, the following tendency is observed: over the analysed period, the percentage of people with secondary education decreased, while the percentage of people with higher education increased. This means that Prison Service officers improved their professional qualifications. This is a good forecast for the future because most often, Prison Service officers improve their professional qualifications on their own initiative. 
6. In the years 1999-2013, people with both secondary and higher education were employed in the penitentiary department; however, those with higher education accounted for the majority. Since 2014, the penitentiary department includes only people with higher education. In the years 2014-2019, Prison Service officers of the penitentiary department most often graduated from the field of study of pedagogy. They completed various specialties, which most often different from the major, i.e. social rehabilitation education. Graduates of social rehabilitation education are a minority in the penitentiary department. Moreover, in the penitentiary department, there were no people who completed their specialisation in penitentiary pedagogy. It is advisable to hire more graduates of rehabilitation pedagogy and penitentiary pedagogy to work in the penitentiary department. In addition, employees of the penitentiary department, who have not completed social rehabilitation education specialisation, should be motivated to improve their professional qualifications, i.e. to complete their education, e.g. at postgraduate studies in the field of rehabilitation pedagogy or penitentiary pedagogy.

\section{References}

Act of 9th April 2010 on the Prison Service (Journal of Laws No. 0, item 523).

Alkhateeb, T.T.Y., Mahmood, H., Altamimi, N.N. \& Furqan, M. (2020). Role of education and economic growth on the CO2 emissions in Saudi Arabia. Entrepreneurship and Sustainability Issues, 8(2), 195-209. http://doi.org/10.9770/jesi.2020.8.2(12)

Bilan, S., Mishchuk, H., Bilan, Y. \& Mishchuk, V. (2019). Empirical Study of Migration Caused by Well-being in Living and Working Environment. Paper presented at the Proceedings of the 34th International Business Information Management Association Conference, IBIMA 2020: Vision 2025: Education Excellence and Management of Innovations through Sustainable Economic Competitive Advantage, 11159-11169.

Chehabeddine, M. \& Tvaronavičienè, M. (2020). Securing regional development. Insights into Regional Development, $2(1), 430-442$. http://doi.org/10.9770/IRD.2020.2.1(3)

Christiana-Kappo, A. \& Ogujiuba. K. (2020). Higher education institutions and corporate social responsibility: triple bottomline as a conceptual framework for community development. Entrepreneurship and Sustainability Issues, 8(2), 1103-1119. http://doi.org/10.9770/ jesi.2020.8.2(66)

Executive Penal Code. Act of 6th June 1997 (Journal of Laws No. 90, item 557.

Hamdan, A., \& Hamdan, R. (2020). The mediating role of oil returns in relationship between investment in higher education and economic growth: Evidence from Saudi Arabia. Economics and Sociology, 13(1), 116-131. http://doi.org/10.14254/2071789X.2020/13-1/8

Kanarek-Lizik D. \& Stankowski W. (2014), From the history of Polish penitentiary facilities, Volume II, The History of the Penitentiary Facility in Inowrocław, POZKAL printing house, Inowrocław.

Kośmider T. (2018) Basics of National Security (of the state) Academic Textbook Academy of the Art of War Warsaw.

Máté, D., Sarihasan I., Popp, J., \& Oláh, J. (2018). The Role of Regional Differences in Immigration: The Case of OECD Countries. Economics and Sociology, 11(3), 190-206. http://doi.org/10.14254/2071-789X.2018/11-3/12

Mazzanti, M., Mazzarano, M., Pronti, A. \& Quatrosi, M. (2020). Fiscal policies, public investments and wellbeing: mapping the evolution of the EU. Insights into Regional Development, 2(4), 725-749. http://doi.org/10.9770/IRD.2020.2.4(1)

Poltarykhin, A. L., Ivanova, V. N. \& Szromnik, A. (2020). Sustainable functioning of educational institutions based on the risk-management implementation mechanism. Entrepreneurship and Sustainability Issues, 8(1), 390-397. http://doi.org/10.9770/jesi.2020.8.1(27)

Regulation No. 89/2020 of the Prison Governor in Włocławek of 27th May 2020 on the organisational structure and the list of positions at the Penitentiary Facility in Włocławek.

Statistical Analysis of the Prison Service in Poland (n.d.). Retrieved Feb 22, 2021 https://www.sw.gov.pl/strona/statystyka-roczna

Strzelec M. Kośmider T. (2019); Considerations on problems of public safety - counteracting threats role of services. Institute of Justice, Warsaw.

Strzelec M. (2019) Methodological foundations of penitentiary studies. Review of Polish Prison System, 102(1), $111-128$.

Vasconcelos, V.V. (2021). Social justice and sustainable regional development: reflections on discourse and practice in public policies 
JOURNAL OF SECURITY AND SUSTAINABILITY ISSUES

ISSN 2029-7017 print/ISSN 2029-7025 online

and public budget. Insights into Regional Development, 3(1), 10-28. https://doi.org/10.9770/IRD.2021.3.1(1)

Dorota KANAREK-LIZIK is the doctor of social sciences in the field of pedagogy, officer of the Prison Service. Currently working at the Psychopedagogical Research Laboratory of the Research and Development Institute at the Higher School of Criminology and Penitentiary Science in Warsaw. Research interests: adaptation of convicts to prison conditions; education of prison service officers.

ORCID ID: orcid.org/0000-0002-1336-3228 